\title{
Investigating Perceptions and Skills of Gifted Students in STEM Education
}

\author{
Selin Kulegel ${ }^{1, *} \&$ Unsal Umdu Topsakal ${ }^{1}$ \\ ${ }^{1}$ Mathematics and Science Education, Yildiz Technical University, Istanbul, Turkey \\ *Correspondence: Mathematics and Science Education, Faculty of Education, Yildiz Technical University, Istanbul, \\ Turkey. E-mail: selin.kgel@gmail.com. https://orcid.org/0000-0001-5920-3396
}

Received: May 4, 2021

Accepted: May 31, $2021 \quad$ Online Published: June 12, 2021

doi:10.5430/wje.v11n3p39

URL: https://doi.org/10.5430/wje.v11n3p39

\begin{abstract}
Science, Technology, Engineering and Mathematics (STEM) provides a noteworthy conceptual lens for many countries when it comes to labor recruitment. For many countries, providing opportunities for gifted students at school and quality STEM education should be included. A limited number of qualitative study has focused in-depth on the skills and perceptions of gifted students in STEM education. Therefore, this article aims to explore gifted students' perceptions and skills by applying STEM education. The study was conducted with 17 middle school gifted students. It includes data collection, a series of interviews, student diaries focusing on the STEM experiences of gifted children, and a self-assessment form that allows students to evaluate themselves in activities. As a result, it was concluded that STEM education practices are important in discovering the perceptions and skills of gifted students, and that students improve their scientific inquiry, argumentation, technological inquiry, and creative thinking skills, and enable career choice to them. In addition, it seems that STEM activities need more work with gifted students.
\end{abstract}

Keywords: gifted students, STEM education, interest, perception, inquiry, career choice

\section{Introduction}

The rapid changes in the new world have brought the need for a quality STEM (Science, Technology, Engineering and Mathematics) education model content that will prepare students for future conditions in the education of gifted students, which has a significant impact on the development of societies (Dailey, 2017; Jolly, 2009) since gifted students need differentiated and enriched learning environment contents (Lee, Baek, \& Lee, 2013). At the same time, gifted students have above-average science knowledge, creativity (Han and Shim, 2019), and high interest, talent (Lee, Matthews, Boo \& Kim, 2020), and motivation (Jang, Chung, Choi, \& Kim, 2013) to keep their interest in these areas alive, and it is important to provide opportunities. Students can reveal their interests and abilities with these educational contents. The STEM education model will provide an important conceptual lens for gifted students.

In the present study, we focused closely on exploring gifted middle school students' skills and perceptions using the STEM education model. Especially, in the science laboratory, students worked in groups with STEM activities, and reflected their specific interests and skills on STEM works. This study examines the effectiveness of the STEM education model in the application of the secondary school curriculum in terms of gifted students.

\subsection{Research Problem}

The developments in our age have revealed the need to raise qualified individuals who can reach solutions by examining the problems of the day. A basic level of potential and advanced knowledge is required to reveal these features. In addition, it is seen that behind all inventions throughout the history of humanity there is a high potential mind and consistent work (Han and Shim, 2019). In this respect, there is a need for gifted students who have contributed to developments throughout history and have been effective in advancing the society (Shim, So, Kim, \& Chang, 2003). Gifted individuals are individuals who keep information in science areas in mind for a long time and learn complex and abstract concepts quickly (Han and Shim, 2019; Jang et al., 2013). In addition, gifted individuals have high creativity, interest (Lee et al., 2020), empathy, risk taking (Han and Shim, 2019; Cho \& Paik, 2006), and 
nature-related leadership traits (Lee et al., 2020). However, the fact that gifted students have competencies in different fields does not mean that they should be successful in every field. Therefore, it is an important factor that the training interventions to be implemented are built on the basis of need, interest, and ability (Lee et al., 2020). Gifted students need differentiated curriculum contents that can reveal their potential, guidance strategies and an education in which they can develop rapidly in their fields (Sattler, 2002). In this respect, various educational approaches have been developed for gifted students today. One of these educational approaches is STEM education. STEM education model is based on a holistic view by developing an interdisciplinary understanding in the solution of macro problems (Bybee, 2010). The main reason for the emergence of STEM education in the USA is that students' interest in engineering, science, and technology is shown to be decreased (Ostler, 2012; Sanders, 2009), which has led to the question of this situation in other countries. Turkey, by including due to a failure in the international arena STEM education curriculum emphasized that the application should be made in this area (MEB, 2018). The realization of STEM education in gifted students will make a significant contribution to solving macro problems with a holistic perspective (Jolly, 2009) because educational strategies such as acceleration, grouping, and integration of creative thinking overlap with the achievements of STEM applications and are supportive to each other (Lee, Baek, and Lee, 2013). There have been educational interventions in many schools in the company of experts on the STEM understanding of gifted students. Students are introduced to STEM fields in various national and international project competitions, and they are involved in studies related to these fields. However, more studies are needed to reveal the interests and perceptions of the students and to support the overall common goal by looking holistic, both socially and cognitively. As a result of the researches, female and male students' perceptions of their ability levels differ depending on gender. It was concluded that girls who are successful in mathematics do not trust themselves compared to men who work in this field, although the students get the same score, the expectations of female students are low (American Association of University Women, 1991). This situation arises from the perception of what level of ability students have rather than their level. In this respect, it is crucial to direct the content in education by examining the perceptions of gifted students in depth.

\subsection{Purpose of the Research}

The goal of the research is to explore perceptions and skills of gifted middle school students using the STEM education model. STEM activities have been developed by taking into account the interdisciplinary principle in line with the integration of the achievements in current science, mathematics, information technologies and software curriculum.

\subsection{Research Questions}

Research questions can be shown as follows: (1) What are the perceptions of gifted middle school students towards the activities prepared according to the STEM education model? (2) What are the skills of gifted middle school students revealed in the activities prepared according to the STEM education model?

\section{Methods}

\subsection{Research Design}

The study explores perceptions and skills of gifted middle school students with the STEM education model. Methodology has a qualitative approach, and a case study has been used. The case study is based on a detailed evaluation of a specific event, process, and individuals (Creswell, 2017).

\subsection{Participants and Procedure}

Participants in the study included the gifted education program of a private secondary school in Turkey were the 5th and 6th grade students. STEM implementations took place in the science lab with good internet connection. The students' ages ranged from 11 to 12 and were divided into four groups. The students had tablet experience and participated in applications with their own tablets. Also, codes were used to protect students' identities. The purposeful sampling method in the study guided the selection of the study participants. The criteria were determined by the researcher and care was taken to have a program that allows gifted students to receive education in school selection. In addition, the students received a gifted education program in science education by the same teacher. We asked the teacher, who has been teaching for several years, to recommend students with higher science knowledge. Interviews were conducted with gifted students to discuss their learning experiences in STEM activities. Moreover, students reflected their STEM artifacts with diaries and self-assessments. Permission was obtained from the Directorate of National Education and program administrators in conducting the study. Parents' consent was obtained for the voluntary participation of the students. 


\subsection{Instruments}

Individual face-to-face interviews were conducted to holistically explore gifted middle school students' perceptions of activities prepared according to the STEM education model. Each student was interviewed for approximately 15-20 minutes. The interviews were recorded and transcribed for analysis. Information about the students was also obtained by talking to the parents on the phone or face to face. In addition, gifted students filled in the student diaries and self-assessment form after each STEM activity. Student diaries are a measurement tool consisting of 5 open-ended questions created to reveal students' perceptions of the STEM artifacts they produce and the process. The students filled in the same time frame after the activities and the researcher waited for them to fill. In addition, gifted students filled out a self-assessment form that allows them to position themselves positively / negatively. The self-assessment form consists of 3 open-ended questions. At the end of each activity, the researcher distributed to each student at the same time in the science laboratory and waited for them to fill in. The filling time ranged from 10-15 minutes. In addition, the students clearly stated on the form the points they did well or had difficulties during the activities.

The student diaries and self-assessment forms were developed by the researchers after a literature review. In addition, 6 experts, including 5 science experts and 1 linguist, were consulted to ensure the validity of these open-ended questions. In the light of the opinions, spelling mistakes were corrected and data collection tools were applied to gifted students in their final form.

Focus group interviews were held with 4 students representing 4 groups in order to discover the skills of gifted middle school students that emerged in the activities prepared according to the STEM education model. It has been noted that 4 students are more entrepreneurial and have higher presentation skills compared to their other friends. The focus group interview was recorded for 30 minutes and transcribed for analysis.

\subsection{Implementation}

In the study, 4 different activities were developed by the researchers in the context of 21 st century problems in the current curriculum focused on STEM project-based learning unit design. These activities lasted 8 weeks (3 lesson hours per week) in the science laboratory with students during the gifted education program. The students were divided into 4 groups and participated in the applications with their own tablets. In the first event, the design of products by producing solutions to the traffic problem with renewable energy sources, the development of the space garbage collector system by drawing attention to the space pollution in the second event, the design of the marine pollution prevention system in the third event, and the headset designs from sound insulation materials in the fourth event were made by the group members. While making these STEM products, students first defined the problem. They conducted research on this problem and in a democratic environment, individuals in each group shared their views with their friends. Also, after the students drew the prototypes of the products, they tested whether their products were working. Finally, each group member presented their designs.

\subsection{Data Analysis}

In order to discover the perceptions and skills of gifted students by applying STEM education, the data obtained from the interviews, diaries and self-assessment form were interpreted in the light of the qualitative paradigm. Focus group interviews were recorded and their analyzes were translated into writing. The analysis of the data was carried out with the content analysis method. The experiences of the participants were organized by coding in categories. In order to ensure reliability, the coders discussed and reached certain classifications and agreed. The consistency rate between evaluators was determined as .93 and reliability was ensured (Miles, Huberman, \& Saldana, 2014).

\section{Results}

Analysis of datasets focused mainly on two main topics: (1) Perceptions of gifted middle school students towards the activities prepared according to the STEM education model, (2) Skills of gifted middle school students revealed in the activities prepared according to the STEM education model.

3.1 Perceptions of Gifted Middle School Students Towards the Activities Prepared According to the STEM Education Model

The first study question was about perceptions of gifted middle school students towards the activities prepared according to the STEM education model. Data obtained from face-to-face individual interviews, diaries and self-assessment were collected, and presented. 
Table 1. Gifted Students' Perceptions Towards Activities of STEM Education Model

\begin{tabular}{|c|c|c|}
\hline Themes & Sub-themes & Description/Examples \\
\hline \multirow[t]{5}{*}{ Product } & Introduce products & $\begin{array}{l}\text { Promoting the products to your } \\
\text { friends as a marketer }\end{array}$ \\
\hline & $\begin{array}{l}\text { Quality and cheap product } \\
\text { selection }\end{array}$ & $\begin{array}{l}\text { Paying attention to quality and cost } \\
\text { when choosing materials }\end{array}$ \\
\hline & Associating products with daily life & $\begin{array}{l}\text { Making sense of the product with } \\
\text { applications used in daily life }\end{array}$ \\
\hline & $\begin{array}{l}\text { Pay attention to the artistic } \\
\text { dimension }\end{array}$ & $\begin{array}{l}\text { Paying attention to the artistic } \\
\text { dimension in the outer design of the } \\
\text { parcel }\end{array}$ \\
\hline & Productivity & $\begin{array}{l}\text { To produce workable prototypes by } \\
\text { turning ideas into reality }\end{array}$ \\
\hline \multirow[t]{2}{*}{ Interdisciplinary subject integrity } & Integrate with different subjects & $\begin{array}{l}\text { Discussing the effect of friction with } \\
\text { air resistance }\end{array}$ \\
\hline & $\begin{array}{l}\text { Integrating science, technology, } \\
\text { engineering and mathematics with } \\
\text { concepts in activities }\end{array}$ & $\begin{array}{l}\text { Associating science with } \\
\text { experiment, technology with tools, } \\
\text { engineering with solid structures, } \\
\text { mathematics with wages }\end{array}$ \\
\hline \multirow[t]{3}{*}{ Skills } & Problem solving & $\begin{array}{l}\text { To develop systematic solutions to } \\
\text { the problem }\end{array}$ \\
\hline & Share the techniques they use & $\begin{array}{l}\text { To share with their friends the } \\
\text { competencies they have learned } \\
\text { while working with silicon }\end{array}$ \\
\hline & Learn engineering applications & $\begin{array}{l}\text { Drawing a prototype before } \\
\text { designing the product is similar to } \\
\text { engineering practices }\end{array}$ \\
\hline Self-criticism & Seeing their good and bad sides & Learn my strengths and weaknesses \\
\hline Career choice & $\begin{array}{l}\text { Career choice is important for the } \\
\text { future and more engineering } \\
\text { profession is preferred }\end{array}$ & $\begin{array}{l}\text { The effects of our applications on } \\
\text { preparing them for computer } \\
\text { engineering, which I will choose in } \\
\text { the future }\end{array}$ \\
\hline \multirow[t]{2}{*}{$\begin{array}{l}\text { Raising awareness by doing } \\
\text { research }\end{array}$} & $\begin{array}{l}\text { To encourage doing research and } \\
\text { projects }\end{array}$ & $\begin{array}{l}\text { Discovering our talents with } \\
\text { projects }\end{array}$ \\
\hline & Become aware of the issues & $\begin{array}{l}\text { Raising awareness to the solution of } \\
\text { problems in daily life }\end{array}$ \\
\hline \multirow[t]{4}{*}{ General reviews } & Little time to complete the activity & $\begin{array}{l}\text { Completing the activity in a limited } \\
\text { time frame }\end{array}$ \\
\hline & Product design is challenging & Gluing the wheel takes a lot of time. \\
\hline & Faster vehicle can be designed & $\begin{array}{l}\text { Faster vehicle design by utilizing } \\
\text { different energy sources }\end{array}$ \\
\hline & Different materials can be used & $\begin{array}{l}\text { Using different materials such as } \\
\text { cotton, styrofoam and sponge to } \\
\text { prevent noise }\end{array}$ \\
\hline
\end{tabular}

As shown in Table 1, It was observed that gifted students introduced the products they designed, and integrated them with different subjects. In addition, it was observed that the students reasoned by generating systematic solution proposals for the problem and learned engineering applications. The students shared the techniques they used. Factors such as encouraging students to research and making projects about the subjects, raising awareness, and enabling cooperation were important contributions of the activities. They paid attention to creating a workable 
prototype and artistic dimension by turning the ideas into reality. They emphasized the necessity of choosing high quality and cheap products by associating the products used with daily life. Also, the students saw their own good and bad sides through the activities they did. Moreover, students associated science with experimentation, technology with the tools they used during the activities, engineering with solid structures, and mathematics with wages. Emphasizing that career choice is important for the future, it was mentioned that engineering profession is at the forefront. Although the students generally had positive thoughts about the activities, they also had negative thoughts. These negative views have actually been focused on criticizing themselves. Criticizing the missing parts of the product, they stated that different materials could be used, a faster vehicle could be designed or the time was too short to complete the activity. What's more, they emphasized that product design is a laborious and challenging job.

\subsection{Skills of Gifted Middle School Students Revealed in the Activities Prepared According to the STEM Education Model}

The second study question was about skills of gifted middle school students revealed in the activities prepared according to the STEM education model. The data obtained from the focus group interview were evaluated in detail in terms of four activities. It was seen that gifted students used basic science knowledge such as reducing friction force and meeting energy from wind in the product they designed in the first activity. They decided to choose the best material by calculating the angle of incidence of the wind in geometric drawings. In this respect, they used their mathematical and engineering skills together. In addition, they have produced solutions for less energy generation by giving examples of applications in advanced technological developments. In the second activity, it was emphasized that the selection is made by using scientific knowledge in material selection and its transfer to different conditions. They used their engineering skills extensively in deciding their place. Also, alternative and unorthodox examples were presented and the students explained their arguments and made them aware of possible dangers. They stated the use of advanced technological products by putting forward the predictions of using less fuel and the end of the energy source with controllable systems from the world. In the third activity, it was seen that they transferred their knowledge of science to design by paying attention to different concepts related to the subject. The students applied the information they learned in different activities by transferring them to this activity. They gave examples by explaining the selection of the materials they used with their reasons. Moreover, they presented their arguments by interpreting scientifically the pointed nose of the ship. They made predictions that a system could be developed by using the bat example they learned in daily life. It has been observed that interdisciplinary integration is used extensively. They used their engineering skills by paying attention to weight in shipbuilding and stated that the absence of engineering practices would pose potential risks. They stated that the design should be ergonomic and by using advanced technology, a machine with a sensor should be transferred to the design to eliminate possible damages to living beings. In the 4th activity, they stated that they put their imaginations into action and that it should be an ergonomic design suitable for the human ear. They discussed the disadvantages of using a bluetooth network instead of a cable. They also had a fun time with their peers.

\section{Discussion, Conclusion and Suggestions}

In this study, we aimed to discover the perceptions and skills of gifted middle school students using the STEM education model. It was determined that students developed their mathematical and engineering skills by using their science knowledge, they were able to integrate the products they designed with different subjects, produced systematic solutions to the problem, and emphasized that the activities were important for the future in choosing a career.

The first study question was about perceptions of gifted middle school students towards the activities prepared according to the STEM education model. The ability of students to integrate a concept in science with different subjects and to associate STEM concepts with science experiment, technology with the tools they use throughout the activities, engineering with solid structures, and mathematics with wages shows that interdisciplinary subject integration is achieved. In addition, integrating engineering applications in STEM by drawing prototypes before designing the product also contributes to interdisciplinary integration. These results are in line with the results of the Roehrig, Dare, Ring-Whalen, \& Wieselmann (2021) study. Roehrig et al. (2021) stated in their study that engineering applications would provide conceptual integration potential within a STEM unit, and that engineering depends on the application of science and mathematics. In this context, the integrated STEM curriculum should be developed, and selected. Another result of the study is that career choice in STEM applications is important for the future, and it was mentioned that more engineering profession is at the forefront. These results are consistent with other studies such as Drymiotou, Constantinou, \& Avraamidou (2021) and Wang, Lin, Chen, Pan, \& Hong (2021), 
but differ in terms of participant groups. For example, 16 students between the ages of 13-15 were included in the research conducted by Drymiotou et al. (2021) in terms of field and participants. They discovered that students' interest in science and their understanding of STEM career increased with opportunities for active participation in scientific applications consisting of career-based scenarios and interaction with experts. On the other hand, Wang et al. (2021) found that learning activities were associated with students' enjoyment of learning science and the intended choice of future STEM career. It also found that students with high scientific competency from Taiwan and Australia made higher preference for future STEM careers than students with low scientific competency. Among the results of the study, the fact that gifted students criticized the parts they deemed missing in the product during the activities and stated that different materials could be used, tools could be designed faster, or that the time was short to complete the activity shows that their critical thinking skills developed. These results are consistent with the results of Liu, He, \& Li (2015) study. Liu et al. (2015) concluded that it is possible to gain knowledge by thinking critically and creatively in traditional classrooms.

The second study question was about skills of gifted middle school students revealed in the activities prepared according to the STEM education model. It was observed that gifted students developed scientific inquiry skills, and argumentation skills by using basic science knowledge throughout the activities. These results are consistent with other studies such as Chen, Pan, Hong, Weng, \& Lin (2020), and Dawson and Carson (2017), but differ in terms of participant groups or study area. For example, 226 typical and 18 gifted students and a case teacher participated in the study conducted by Chen et al. (2020). They discovered that typical students and gifted students could participate in scientific inquiry-based learning with positive emotional perception. On the other hand, Dawson and Carson (2017) found that scenarios related to socio scientific issues (SSI) improve students' argumentation skills. In this context, argumentation skills can be focused in STEM studies. Another result of the research is that the students develop their creative skills by presenting different examples. These results are in line with other studies such as Wang, Lin, Chen, Pan, \& Hong (2021), Ozkan and Topsakal (2019) and Jamali (2019). For example, Wan et al. (2021) found that direct and explicit approaches are necessary to develop students' STEM creativity more effectively; Ozkan and Topsakal (2019) improved the verbal and figural creativity of middle school students with the STEM design program with art content. Also, Jamali (2019) showed that LEGO robotic activities positively contribute to the development of creative thinking skills of gifted students. In this context, more research should be done in developing creative thinking skills of gifted students. Among the results of the study, it was observed that advanced technological knowledge increased, and technological inquiry skills improved. For instance, Lin, Hsiao, Williams, and Chen (2020) discovered that 6E-focused STEM hands-on activities have a positive effect on secondary school students' technological inquiry skills.

As a result, using the STEM education model, it has been discovered that gifted students develop their mathematical and engineering skills by using their science knowledge, provide interdisciplinary subject integrity, critical thinking, and the STEM education model is effective in career choice. In addition, gifted students developed their scientific inquiry, argumentation, technological inquiry and creative thinking skills thanks to these practical activities. In this context, the use of activities prepared according to the STEM education model is beneficial for developing gifted students' perceptions and skills. Many studies on the education of gifted students suggest the use of the STEM model and are in line with the results of this study (So, Kim, \& Ryoo, 2020; Morris, Slater, Fitzgerald, Lummis, \& van Etten, 2019; Jamali, 2019; Sternberg, 2019; Han and Shim, 2019; Stoeger, Hopp, \& Ziegler, 2017).

\section{References}

American Association of University Women. (1991). Shortchanging girls, shortchanging America: Washington, DC: Author.

Bybee, R. W. (2010). What is STEM Education? Science, 329(5995), 996-996. https://doi.org/10.1126/science.1194998

Chen, Y. C., Pan, Y. T., Hong, Z. R., Weng, X. F., \& Lin, H. S. (2020). Exploring the pedagogical features of integrating essential competencies of scientific inquiry in classroom teaching. Research in Science \& Technological Education, 38(2), 185-207. https://doi.org/10.1080/02635143.2019.1601075

Cho, E. B., \& Paik, S. H. (2006). A comparison analysis of intellectual characteristics between science-gifted education students and general students. Journal of the Korean Association for Science Education, 26(3), 307-316.

Creswell, J. W. (2017). Research design: Qualitative, quantitative, and mixed methods approaches (4th ed.). Sage 
publications.

Dailey, D. (2017). Using engineering design challenges to engage elementary students with gifts and talents across multiple content areas. Gifted Child Today, 40(3), 137-143. https://doi.org/10.1177/1076217517707236

Dawson, V., \& Carson, K. (2017). Using climate change scenarios to assess high school students' argumentation skills. Research in Science \& Technological Education, 35(1), 1-16. https://doi.org/10.1080/02635143.2016.1174932

Drymiotou, I., Constantinou, C. P., \& Avraamidou, L. (2021). Enhancing students' interest in science and understandings of STEM careers: the role of career-based scenarios. International Journal of Science Education, 1-20. https://doi.org/10.1080/09500693.2021.1880664

Han, H. J., \& Shim, K. C. (2019). Development of an engineering design process-based teaching and learning model for scientifically gifted students at the Science Education Institute for the Gifted in South Korea. Asia-Pacific Science Education, 5(1), 1-18. https://doi.org/10.1186/s41029-019-0047-6

Jamali, U. A. Y. (2019). Fostering creativity using robotics among gifted primary school students. Gifted and Talented International, 34(1-2), 71-78. https://doi.org/10.1080/15332276.2020.1711545

Jang, J., Chung, Y., Choi, Y., \& Kim, S. W. (2013). Exploring the characteristics of science gifted students' task commitment. Journal of the Korean association for science education, 33(1), 1-16. https://doi.org/10.14697/jkase.2013.33.1.001

Jolly, J. L. (2009). Historical perspectives: The national defense education act, current STEM initiative, and the gifted. Gifted Child Today, 32(2), 50-53. https://doi.org/10.4219/gct-2009-873

Lee, S. W., Baek, J. I., \& Lee. J, G. (2013). The development and the effects of educational program applied on STEAM for the mathematical prodigy. Education of Primary School Mathematics, 16(1), 35-55. https://doi.org/10.7468/jksmec.2013.16.1.035

Lee, S. Y., Matthews, M., Boo, E., \& Kim, Y. K. (2020). Gifted students' perceptions about leadership and leadership development. High Ability Studies, 1-41. https://doi.org/10.1080/13598139.2020.1818554

Lin, K. Y., Hsiao, H. S., Williams, P. J., \& Chen, Y. H. (2020). Effects of 6E-oriented STEM practical activities in cultivating middle school students' attitudes toward technology and technological inquiry ability. Research in Science \& Technological Education, 38(1), 1-18. https://doi.org/10.1080/02635143.2018.1561432

Liu, Z. K., He, J., \& Li, B. (2015). Critical and creative thinking as learning processes at top-ranking Chinese middle schools: possibilities and required improvements. High Ability Studies, 26(1), 139-152. https://doi.org/10.1080/13598139.2015.1015501

MEB. (2018). Ortaokul fen bilimleri dersi öğretim programı. Ankara: Milli Ĕ̆itim Bakanlığı Talim Terbiye Kurlu Başkanlı̆̆l.

Miles, M. B., Huberman, M. A., \& Saldana, J. (2014). Drawing and verifying conclusions. Qualitative data analysis: A methods sourcebook, 275-322.

Morris, J., Slater, E., Fitzgerald, M. T., Lummis, G. W., \& Etten, E. (2019). Using local rural knowledge to enhance STEM learning for gifted and talented students in Australia. Research in Science Education, 1-19. https://doi.org/10.1007/s11165-019-9823-2

Ostler, E. (2012). 21st century STEM education: A tactical model for long-range success. International Journal of Applied Science and Technology, 2(1), 28-33.

Ozkan, G., \& Topsakal, U. U. (2019). Exploring the effectiveness of STEAM design processes on middle school students' creativity. International Journal of Technology and Design Education, 31, 95-116. https://doi.org/10.1007/s10798-019-09547-z

Roehrig, G. H., Dare, E. A., Ring-Whalen, E., \& Wieselmann, J. R. (2021). Understanding coherence and integration in integrated STEM curriculum. International Journal of STEM Education, 8(1), 1-21. https://doi.org/10.1186/s40594-020-00259-8

Sanders, M. (2009). Stem, stem education, stem mania. The Technology Teacher, 68(4), 20-26.

Sattler, J. M. (2002). Assessment of children. Behavioral and clinical implications (4th ed.). San Diego: Jerome M. Sattler, Publisher, Inc

Shim, K. C., So, K. H., Kim, H. S., \& Chang, N. K. (2003). Preference of science gifted/talented and general 
students for study course and occupation. Biology Education, 31(4), 292-298.

So, H. J., Kim, D., \& Ryoo, D. (2020). Trajectories of Developing Computational Thinking Competencies: Case Portraits of Korean Gifted Girls. The Asia-Pacific Education Researcher, 29(1), 85-100. https://doi.org/10.1007/s40299-019-00459-z

Sternberg, R. J. (2019). Teaching and assessing gifted students in STEM disciplines through the augmented theory of successful intelligence. High Ability Studies, 30(1-2), 103-126. https://doi.org/10.1080/13598139.2018.1528847

Stoeger, H., Hopp, M., \& Ziegler, A. (2017). Online mentoring as an extracurricular measure to encourage talented girls in STEM (science, technology, engineering, and mathematics): An empirical study of one-on-one versus group mentoring. Gifted Child Quarterly, 61(3), 239-249. https://doi.org/10.1177/0016986217702215

Wan, Z. H., So, W. M. W., \& Hu, W. (2021). Necessary or sufficient? The impacts of epistemic beliefs on STEM creativity and the mediation of intellectual risk-taking. International Journal of Science Education, 1-21. https://doi.org/10.1080/09500693.2021.1877368

Wang, H. H., Lin, H. S., Chen, Y. C., Pan, Y. T., \& Hong, Z. R. (2021). Modelling relationships among students' inquiry-related learning activities, enjoyment of learning, and their intended choice of a future STEM career. International Journal of Science Education, 43(1), 1-22. https://doi.org/10.1080/09500693.2020.1860266

\section{Copyrights}

Copyright for this article is retained by the author(s), with first publication rights granted to the journal.

This is an open-access article distributed under the terms and conditions of the Creative Commons Attribution license (http://creativecommons.org/licenses/by/4.0/). 